\title{
10
}

\section{Cooperative approaches to marine resource management in the South Pacific}

\section{Colin Hunt}

New cooperative approaches to the management of marine resources are imperative in the delivery of sustainable incomes and livelihoods in the South Pacific. While recent international agreements have strengthened the sovereignty of states over their adjacent ocean resources, the actual development and implementation of management regimes for tuna, arguably the region's most important renewable resource in terms of income-generating potential, will require a much more concerted approach by Pacific island states. This will need to be matched by a willingness on the part of the non-coastal states that traditionally harvest the bulk of the region's oceanic resources to cooperate in tuna management. The alternative is the eventual depletion of the great tuna stocks.

In the case of inshore resources, there is a new assertiveness being demonstrated by local communities toward customary tenures. In some instances, local tenures are being reinforced by regional and national governments. Such cohesion between governments and communities, in the face of increasing resource exploitation, is enhancing the prospects for sustaining the livelihoods of coastal communities.

In this chapter, common property issues concerning South Pacific marine resources will be divided by location-offshore and inshoreand their use will be categorised as either commercial/industrial or subsistence. 


\section{Commercial and subsistence uses}

The value of commercial fishing in the South Pacific is in the order of US $\$ 2$ billion annually, with tuna alone having a total market value of some US $\$ 1.5$ billion. About half the world's canning tuna comes from this region.

One way of measuring the importance of fishing sectors to Pacific island economies is to express fishing revenue as a proportion of total government revenue. In the case of Kiribati and Tuvalu, the proportion is between 30 and 50 per cent. It is also high in the Federated States of Micronesia and Marshall Islands. This is expected because these countries receive significant licence fees from foreign vessels. Kiribati and Tuvalu also receive significant repatriated revenues from their citizens that crew foreign vessels.

If we measure fishing by share of GDP, we find that it is 9-10 per cent in Solomon Islands, Kiribati and Tuvalu but only 1.5 per cent in Fiji. The latter economy is diversified and fishing is just one of several important sectors. The developed industrial fisheries and export canneries of both Solomon Islands and Fiji mean that formal employment is significant in their fisheries sectors.

The inshore waters of the Pacific islands are relatively abundant. This fact, and the ease of access for vessels, means that coastal waters are the locus of fishing and gathering activity that provides a large proportion of dietary protein. However, most inshore species are vulnerable to overfishing.

The majority of the population in most of these countries are still in a subsistence economy. Despite the increase in fishing for cash, a large proportion of the catch is still consumed by the fishers, or shared, and does not enter markets. Subsistence fishing's importance or dominance means that the true importance to the island states of their marine resources is not reflected in budget estimates or national accounts.

Commercial fishing in inshore waters includes prawns (in Papua New Guinea), reef and deep slope fish, as well as beche-de-mer and molluscs such as trochus and greensnail. There is also a substantial bait fishery in Solomon Islands coastal waters supplying the pole-andline tuna fleet of canner Solomon Taiyo.

Figure 10.1, by showing estimates of the value of fish taken in the coastal waters of selected Pacific island countries, provides a more comprehensive appreciation than national accounts of the importance of commercial vis-à-vis subsistence fishing and also of the relative size of the coastal fisheries by country. It is clear that the value of subsis- 
tence fishing is significant in most countries and that in several countries it has a value of many millions of dollars.

Figure 10.1: Coastal fisheries value (mean of 1989-1994)

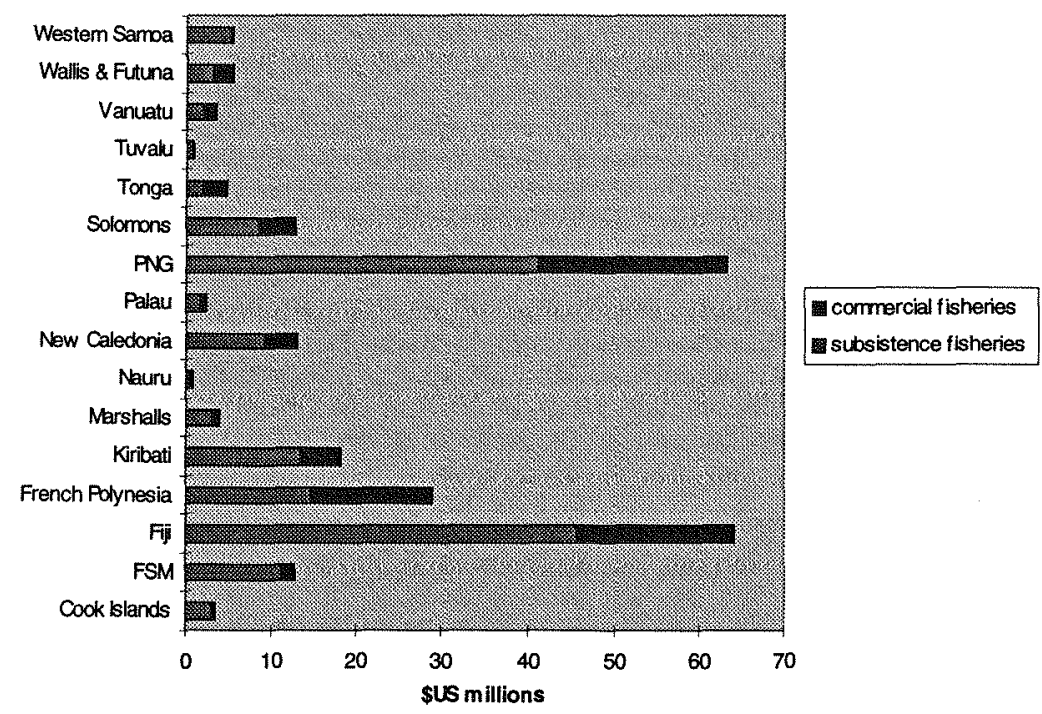

Note: 1 . While the source of data for this figure does not provide a definition of 'coastal waters' the term is assumed to be synonymous with territorial seas, ie; within 12 nautical miles of the coast.

2. Details of the method of imputation of the value of subsistence fishing are not given by the source therefore the actual and relative values of subsistence fishing shown in Figure 2 should be used only as guides.

Source: Dalzell, P., Adams, T., and Polunin, N., 1995. 'Coastal fisheries in the South Pacific', paper to the joint FFA/SPC workshop, Management of South Pacific Inshore Fisheries, 26 June-7 July, 1995, South Pacific Commission, Noumea, unpublished:149.

\section{UNCLOS and its provisions}

Tenure over, or access rights to, marine resources is crucial to their management. However, 'open access' has characterised the exploitation of all ocean resources outside the 3 nautical mile $(\mathrm{nm})$ territorial limits. Article 2 of the 1958 Geneva Convention on the high seas said that freedom of fishing was one of the established freedoms of the high seas. The implication was that coastal states could not 
exclusively appropriate or manage marine resources adjacent but outside their territorial waters.

Under open access, marine resource users are unrestrained and competitive, maximising their present harvests to the detriment of the resource, the ecosystem, themselves, society, and future generations. The potential to control open-access fishing was radically enhanced by the UN's adoption of the UN Convention on the Law of the Sea (UNCLOS) on 30 April 1982 (UN 1982). From its adoption to its ratification, in late 1994, the major provisions of the convention have in fact been in force, being interpreted as representing 'customary ocean law'.

The UNCLOS agreement expanded territorial seas to $12 \mathrm{~nm}$ and created $200 \mathrm{~nm}$ zones (exclusive economic zones, EEZs) around coastal states. The 'sovereign rights' of the coastal state apply to the exploitation and conservation of living and non-living natural resources (UN 1982, Article 55). The extended rights and jurisdictions of several South Pacific coastal states were enhanced by the application of EEZs to islands no matter what their distance from the coast. With the rights go responsibilities, however. Coastal states are required to determine total allowable catches in their exclusive economic zones. They must also implement management measures in cooperation with relevant regional organisations. For their part, fishing states must contribute fishing statistics (UN 1982, Article 61).

All island states have declared extended maritime zones. Table 10.1 sets out the area of EEZs for South Pacific states. It shows the great variation in size of EEZs and in industrial tuna catch. The reluctance of several island states to ratify UNCLOS and to sign the agreement for the implementation of UNCLOS relating to conservation and management of straddling and highly migratory fish stocks, is probably related to the costs of implementation of the laws and agreements.

In the light of total allowable catches and management plans, coastal states that do not have the capacity to harvest the entire total allowable catch shall give other states access to the surplus in their EEZs. In providing access to other states, a coastal state shall consider the significance of the resource to its economy on the one hand, and the needs of nations that have habitually fished in the EEZ on the other. The nationals of other nations must however comply with the conservation measures and other terms and conditions of access (such as licensing and licence fees, provision of catch and effort statistics, port landings and enforcement) established in the laws of the coastal states (UN 1982, Article 62). The access rights of geographically 
disadvantaged states-coastal states whose position makes them dependent for supplies of fish from resources of the EEZs of other states-are catered for in Article 70.

Table 10.1 Marine sector profiles, South Pacific

\begin{tabular}{|c|c|c|c|c|}
\hline States & $\begin{array}{r}\text { EEZ or } \\
\text { EFZ } \\
\text { area } \\
0 \mathrm{kmsq}\end{array}$ & $\begin{array}{r}\text { Tuna } \\
\text { harvest } \\
\text { (industrial) } \\
1992, \text { tonnes }\end{array}$ & $\begin{array}{l}\text { Ratified(r) } \\
\text { UNCLOS }\end{array}$ & $\begin{array}{r}\text { Signed(s) } \\
\text { ratified(r) } \\
\text { USS \& HMS } \\
\text { Agreement }^{\mathrm{A}}\end{array}$ \\
\hline Cook Islands & 1830 & 10 & $\mathrm{r}$ & \\
\hline FSM & 2978 & 149416 & & \\
\hline Fiji & 1290 & 447 & $r$ & \\
\hline Kiribati & 3550 & 113951 & $r$ & \\
\hline Marshall Islands & 2131 & 24959 & $r$ & $\mathbf{s}$ \\
\hline Nauru & 320 & 21200 & $r$ & \\
\hline Niue & 390 & n.a.c & & s \\
\hline Palau & 629 & 5317 & & \\
\hline PNG & 3120 & 93374 & & s \\
\hline Solomon Islands & 1340 & 40689 & & \\
\hline Tonga & 700 & 181 & $r$ & $s, r$ \\
\hline Tuvalu & 900 & 5495 & & \\
\hline Vanuatu & 680 & 329 & & \\
\hline Western Samoa & 120 & 27 & $r$ & $\mathrm{~s}$ \\
\hline Other & & 24213 & & \\
\hline sub-total & 19978 & 479608 & & \\
\hline \multicolumn{5}{|c|}{ Dependent Territories } \\
\hline American Samoa & 390 &.. & & US s, $r$ \\
\hline French Polynesia & 5030 &.. & Fr r & \\
\hline Guam (US) & 218 & .. & & \\
\hline New Caledonia (Fr) & 1740 &.. & & \\
\hline N. Marianas (US) & 1823 &.. & & \\
\hline Pitcairn Island (UK) & 800 &.. & & UKs \\
\hline Tokelau (NZ) & 290 &. & $\mathrm{NZr}$ & $\mathrm{NZs}$ \\
\hline Wallis \& Futuna (Fr) & 300 &.. & & \\
\hline sub-total & 10569 &.. & & \\
\hline Total & 30569 &.. & & \\
\hline
\end{tabular}

Notes: a EFZs, Extended Fishing Zones, are precursors of the EEZs and also have a breadth of $200 \mathrm{~nm}$. bAgreement for the implementation of UNCLOS relating to conservation and management of straddling and highly migratory fish stocks. Sources: Ron Duncan and Ila Temu, 'Trade, investment and sustainable development of natural resources in the Pacific: the case of fish and timber', paper presented to the Economic and Social Commission for Asia and the Pacific Expert Group Meeting on Enhancing Cooperation in Trade and Investment Between Pacific island Countries and Economies of East and South East Asia in the 1990s, Port Vila, Vanuatu, July, 8-12, 1996, unpublished; United Nations Internet site, http://www.un.org/Depts/los/losg4st.htm; Tsamenyi, B., and Mfodwo, K., 1995. 'South Pacific island states and the new regime of fisheries: issues of law, economy and diplomacy', in J. Crawford and D. Rothwell (eds), The Law of the Sea in the Asian Pacific region, Martinus Nijhoff, Dordrecht:121-53, Table 1. 
Where the same fish stocks are found in more than one coastal state, the states must cooperate for the conservation and development of the stocks, directly or through regional organisations (UN 1982, Article 63). Where highly migratory species are present, their conservation and optimum utilisation is to be achieved by cooperation between the coastal state, fishing states and appropriate organisations (Article 64). And even in the case of the high seas-areas outside EEZs-states are bound to conserve stocks through cooperation and establishment regional organisations (Article 117).

UNCLOS has formally endowed Pacific island states with extensive marine resources and has formulated internationally recognised frameworks to manage them.

The agreement (UN 1995) governing straddling and highly migratory fish stocks, commonly known as the 'Implementing Agreement', reinforces the Law of the Sea provisions. It has important implications for the Pacific because tuna stocks straddle and migrate through EEZs and the high seas. The agreement charges coastal states and fishing states to agree upon measures for the conservation of stocks and, with respect to migratory species, their optimum utilisation (Article 7). The agreement was signed by 44 countries and at 16 September 1996, it had been ratified by three nations of the thirty required to bring it into force (Table 10.1).

The implications for the regional organisations, the Forum Fisheries Agency (FFA) and the South Pacific Commission (SPC), are that the vehicle for conservation measures is envisaged by the agreement to be regional or sub-regional management organisations. The fishing states are expected either to become a member of the regional organisations or to agree to apply management measures established by such organisations. Moreover, coastal and fishing states should participate in the work of such organisations (Article 8).

The implications for the collection and analysis of data are important given that states are charged with the provision of comprehensive catch and effort data to regional authorities covering both target and non-target species for EEZs and high seas areas (Articles 3 and 5).

Even though some are published by SPC (1994a), data from foreign tuna longline vessels (which account for over half of the total value of the South Pacific tuna fishery) is presently deficient for purposes of management of the stocks of yellowfin, bigeye, albacore and of associated by-catch species. The status of bigeye, albacore and by- 
catch species is particularly uncertain under heavy fishing pressure (SPC 1994b, SPC 1996). Data is also deficient for EEZs and for the adjacent high seas areas. The latter yield approximately half of the longline catch, but only the Japanese fleet presently provides the SPC with statistics on its high seas catch and this is in aggregated rather than logbook form (personal communication, Dr Antony Lewis, Oceanic Fisheries Coordinator, SPC). The intergovernmental management of tuna is analysed in more detail in Oh's chapter.

\section{Environmental issues}

The ratification of UNCLOS also requires countries to adopt, implement, and enforce the rules and standards applying under global treaties governing the marine environment. An example is the International Convention on the Prevention of Pollution from Ships (MARPOL), in place since 1983 and supported by the London Dumping Convention, governing the disposal of ship waste (dumped plastics are particularly dangerous to many marine animals). However, the provisions of this treaty will be effective only if coastal states install shore-based facilities to deal with ship waste. In their absence, ships will pollute the oceans by discharging or incinerating waste at sea.

Land-based pollution is, however, by far the most deleterious to the marine environment, with productive inshore waters bearing the brunt. And, while UNCLOS (Article 207) specifies that such pollution should be prevented or controlled, its provisions are unlikely to be effective for two reasons: the thinness of the recommendations, and the cost and difficulty of pollution control.

Although few countries in the South Pacific are industrialised and populations and densities are relatively low, pollution is serious in some coastal locations, lowering the productivity of resources and causing health problems (Hunt 1996). A regional cooperative approach to deal with coastal pollution is being undertaken by the South Pacific Regional Environment Programme. Problems have been identified through 'state of the environment' reporting and are being addressed through the National Environmental Management Strategies.

But progress in pollution prevention and control in the South Pacific will depend on the application of resources and political will.

The worst violators are government agencies who, on the one hand, promote government protection but not at the cost of the developing project, such as mining and tourism development (UN, undated, cited by Boer 1995:91). 


\section{Inshore management}

In the case of the inshore waters of Oceania, the most widespread and important measure for the conservation of marine resources has been controlled access through customary marine tenure arrangements. The rights to fish are controlled by a clan, chief or family. Traditonally, there was no 'ownership' by one group of all rights, but rather a system of allocation of access and use rights. In customary marine tenure, social boundaries are as important as physical boundaries but harder for outsiders to define (Crocombe 1994).

Seasonal closure is one of the measures adopted under customary marine tenure to conserve stocks. The conservation of stocks through such restraints yielded substantial benefits to the right holders (Johannes 1978). However, while acknowledging the management implications of restricting access, Hyndman (1993) argues that tenure systems were probably not developed with conservation per se in mind. The purposes were rather to embed aquatic resources in the gift economy and the kinship modes of production, or as Carrier (1987:164, cited by Hyndman 1993) succinctly put it '[customary marine tenure] made it possible to be generous'.

Thus, while customary laws are the basis for decision-making concerning access and the sanctions that might apply in the case of breaches, such laws are flexible in that there are constant negotiations at the community level regarding access and use. And the principles underlying customary marine tenure are subject to continuous interpretation, transformation, and redefinition (Scheffler and Larmour 1987). Indeed, the customary marine tenure of today has very little in common with that of 200 years ago (Crocombe 1994).

Change and erosion of traditional customary marine tenure has occurred largely because of coastal population decreases in the early stages of colonisation, and subsequent population increases (about 3.5 million people now live on the coast in the South Pacific), adoption of technology (fishing power and mobility), the intrusion of the cash economy and a breakdown of chiefly authority (Johannes 1978;

Crocombe 1994).

Scientific methods of fisheries management require a knowledge of the biology of target species and the availability of catch and effort data. But, except in a few cases, the data required for scientific fisheries management for inshore waters in the Pacific is not available. Much time-consuming and expensive research is required before 
Western-style management can be effected widely, indeed, 'from a management perspective it is unlikely that the Pacific island reef fisheries recruitment processes will ever be sufficiently understood to be incorporated into management initiatives' (Dalzell et al. 1995:80). The task is exacerbated by the archipelagic nature of many Pacific island countries. Moreover, centrally imposed scientific management for inshore fisheries increases the monitoring and regulatory responsibilities of governments. But the fisheries departments in Pacific island countries are typically understaffed and underfunded.

Given the pressing need to manage inshore fisheries and the scarcity of resources, alternative management models have been proposed (Dalzell et al. 1995; Johannes 1994a; 1994b; Petelo et al. 1995). These alternative models strengthen rather than weaken customary marine tenure. Legislative support for local tenure arrangements allows the reintroduction of effective traditional methods, such as temporary closures.

In the alternative models, local knowledge substitutes for, or complements, scientific data, while local planning substitutes for, or complements, fisheries department planning.

The need for inshore management plans is most pressing in some of the smaller islands and atolls where greatly increased fishing effort on fish stocks is jeopardising the supply of essential protein to rapidly growing populations (Dalzell et al. 1995). The harvesting of commercial invertebrates such as trochus and bêche-de-mer (which in many cases have been severely depleted) can also come under local management arrangements.

\section{The importance of institutional arrangements}

We saw how UNCLOS is fundamental to the management of industrial fisheries in that it has enabled the coastal states to exclude or license foreign fishing and thus control fishing efforts in their EEZs. However, the main species of tuna are common to the South Pacific and are migratory. Therefore, the size of local catches of tuna are determined to some extent by the fishing of the same species in other EEZs. The commonality and the mobility of stocks dictate the need for a regional approach to tuna management.

Fortunately, regional institutions are already in place to give effect to regional planning. The FFA in Honiara acts on behalf of members in generating fishing policy options and providing a regional forum for 
their discussion, while the SPC in Noumea collects, analyses, and disseminates catch and effort data (for tuna and other species) to its members. These institutions will have an indispensable role to play in maximising the benefits to Pacific island countries of their marine resources and in the development and implementation of regional resource management plans.

It needs to be emphasised, however, that presently there is no regulation of the level of tuna catch by species. The participants in the industrial fisheries have every incentive to maximise their harvests. A regional plan would need to apply not just to EEZs but to high seas where the common regional stocks are found and where fishing effort by industrial distant water fleets is considerable.

At the local (inshore) level, just as in the case of EEZs, tenure and access rights to marine resources should be clearly defined, otherwise there is a tendency for open access to prevail (Hunt 1996). The tenured group can then make access arrangements and exclude unwanted effort.

A powerful incentive for local groups to restore and enhance customary marine tenure is the acknowledgment of their jurisdiction by local and central government, and the endorsement of their plans. In some cases the acknowledgment of tenure and plans means that the local group has recourse to the law of the country in upholding local access rules.

\section{International cooperation}

While there are significant industrial fishing operations based in Fiji, American Samoa and Solomon Islands, the migratory tuna stocks are mainly exploited by distant water nations supplying markets in the United States and Asia. Through the licensing vessels under these flags Pacific island countries receive about US $\$ 70$ million from a fishery worth some US $\$ 1.5$ billion. The dominant fleets are those of the United States, Japan, Taiwan, and the Republic of Korea.

The Pacific island countries have jurisdiction over their EEZs and their collective jurisdiction covers much of the tuna fishing grounds of the central, western and south Pacific, while the FFA and the SPC allow the exercise of collective power. Despite this, there is only one multilateral fishing agreement in place-the one between several Pacific island countries and the US tuna fleet. ${ }^{2}$ All other foreign fleet access is through bilateral negotiation between individual island states and the representatives of the various national fleets. 
While the FFA has developed harmonised terms and conditions of fishing and effected economies of scale in regional monitoring and surveillance, there is still variation in the level of licence fees as a proportion of value of catch (Maxwell and Owen 1994). The Pacific island countries put themselves in weak negotiating positions in that the distant water nations can threaten to walk away and take their fishing fees elsewhere. They are also particularly vulnerable to persuasion that access fees to tuna should be concessional because of the level of aid being supplied. Japan has consistently rejected multilateral frameworks on this latter ground (Doulman 1989; Tsamenyi and Mfodwo 1995).

A major constraint on the development of a united approach to negotiations with the distant water fleets is the unwillingness of some island states that depend heavily on fishing fees, for example Kiribati and the Federated States of Micronesia (FSM), to adopt the cooperative model. Both have been vocal in their opposition to multilateral agreements (Pacific Report 1995, 1996; Islands Business Pacific 1994) although they have not ruled out united sub-regional approaches to negotiations by the tuna-rich countries under the Palau Agreement. $^{3}$

The limitation of sub-regional approaches are illustrated by the recent rejection by Taiwan of specific attempts by Pacific island countries to negotiate a sub-regional agreement. ${ }^{4}$ If all FFA countries -including FSM and Papua New Guinea, which host considerable Taiwanese fishing efforts (SPC 1994a)-have given weight to the negotiations, there would have been a far greater probability of the conclusion of a beneficial sub-regional longline agreement.

The FSM fears that it could be worse off under multilateral agreements and sees present bilateral arrangements as providing more opportunities for domestic fisheries development. It will confine regional approaches to the setting of umbrella terms and conditions under which bilateral deals are made.

In the face of the difficulty in negotiating increased access fees with distant water nations, the policy adopted by Pacific island countries to achieve greater economic benefits from their tuna stocks is one of trying to develop local fishing operations. The development of domestic tuna industries is taking two forms. First, by the encouragement of local short-trip longlining operations that supply sashimi export markets (short-trip longlining has the potential to confer substantial benefits on Pacific island countries (ESCAP 
forthcoming; South Pacific Project Facility 1995)). Second, through regional arrangements that encourage purse-seine vessels to base locally, instead of at foreign ports. ${ }^{5}$

The economic benefits of the second thrust of localising purse-seine vessels has not been demonstrated. A preliminary analysis suggests that the fishing rents or profits of distant water vessels would be curtailed by localisation as would their consequent ability to pay fishing royalties.

\section{Local cooperation}

As mentioned above, there are several factors which are tending to break down the customary marine tenure that previously enabled the conservation of inshore (as opposed to offshore) marine resources. The introduction of cash benefits in exchange for access by industrial or commercial fisheries is one of these factors: this is evident in Papua New Guinea, Solomon Islands, Marshall Islands and Fiji. Narrow groups or spokespersons, not fully representative of the traditional descent groups, have been able to appropriate rents for their own use (Crocombe 1994, Turner 1994, Hviding 1996).

While acknowledging that customary marine tenure may present impediments to governments undertaking industrial fisheries development, I would argue that strengthening customary marine tenure, rather than weakening it, should often be the preferred policy. The reasons are threefold.

First, in many countries, subsistence fishing dominates and the local communities that are dependent on the resources for their livelihoods should be in a position to manage those resources. Second, the development and resilience of management and conservation plans for commercial resources by governments in cooperation with communities is facilitated by clear access rights. Third, where commercial exploitation of local resources is a possibility, for example in the cases of trochus or beche-de-mer, strengthened customary marine tenure puts the local communities in a more advantageous position in negotiating with traders. In some Pacific island countries, customary marine tenure is already reinforced by central governments. For example, local rights are recognised by the Fiji Fisheries Commission (Cook 1994), and in Solomon Islands (over both land and fisheries) through the Provincial Government Act of 1971 (Crocombe 1994, Pulea 1993). 
Central governments have been prone to ignore the difficult process of clarifying customary marine tenure and carrying out development or conservation through 'top down' approaches. However, the resilience of any development or conservation arrangements is heavily dependent, in the Pacific, on local people being involved in decision processes and receiving rents from any arrangement. $^{6}$

\section{Cooperative models}

The arrangements for intergovernmental cooperation in tuna management are analysed in the following chapter by Oh. Here I simply summmarise the advantages of cooperation.

Intergovernmental cooperation

- should generate higher royalties by increasing Pacific island countries' negotiating power, and breaking the nexus between fishing access fees and development aid

- facilitates the introduction of control of fishing effort on regional tuna stocks by

input controls (gear and/or vessels numbers), or output controls (quotas)

- reduces transaction costs to both sides

- makes the content of agreements transparent, compared with bilateral arrangements

- facilitates co-management arrangements with other coastal states (outside existing forums) in the region that exploit the common tuna stocks

- facilitates co-management arrangements with distant water fleets in the region that exploit the common tuna stocks.

For inshore areas, however, the thrust should not be so much in the documentation of customary marine tenure but in its definition and strengthening so that it can be effective in developing local arrangements, and can integrate more effectively with planning and policy, for marine resource management and conservation, of central governments (Hyndman 1993).

A cooperative approach between communities, acting in their local interests, and governments, acting in the national or public interest, has much to offer. Strengthened customary and local resource management arrangements, albeit based of necessity on customary practices rather than scientific fisheries management principles, can 
assist the central government in its overall policy of conservation of marine resources (as set out, for example, in National Environmental Management Strategies).

An example of where the strengthening of customary marine tenure has assisted the declaration of a protected area is provided by the work of Tacconi under an Australian Council for International Agricultural Research project in Vanuatu.

A very significant step in biodiversity conservation in Vanuatu is the development of provincial legislation, under the national constitution, enabling local groups to strengthen their property rights and hence their ability to protect and to manage their natural resources. This step was the direct result of Tacconi's negotiations with the Attorney General's department and using a draft by-law (obtained from Santa Ysabel province, Solomon Islands) as a model. ${ }^{8}$ Such legislation has been adopted in principle by the local government councils of Santo and Malekula, and has been enacted in Efate (Bennett 1996).

In 1994 the local government region of MALAPA, which includes Malekula, was empowered to create protected areas by the passage through the Vanuatu Parliament of the Bill for Decentralisation and Local Government Regions, Act No. 1, of 1994. MALAPA was now able to introduce by-laws that 'outline create and draw up regulations governing the environmental protection zones (natural parks, natural reserves or tourist-attraction areas in the national interest' (Act 1, Section 20[9]).

Tacconi subsequently assisted MALAPA in drawing up a by-law that facilitates planning by local ni-Vanuatu (Tacconi 1995a). Features of the by-laws are as follows.

- Areas are protected on the basis of custom, amenity, and livelihood provision.

- The regional council by-laws (under national legislation) strengthen customary tenure by making it an offence to contravene the rules governing a protected area.

- The term of the by-law is specified by the landowners.

- Amendments may be made by landowners to a by-law at any time.

- For every declared protected area a committee of management is set up, representative of both landowner interests and community interests (through chiefly representation). 
An important feature of the by-law legislation is that it is distinct from, but complements, the Vanuatu National Parks Act, No. 7 of 1993. This latter act is designed to protect unique ecosystems, habitats of threatened species or areas possessing outstanding features. The bylaw, in contrast, allows the protection of natural areas that are significant in the support and maintenance of livelihoods (Tacconi 1995a).

An important characteristic of the protected areas that have arisen under by-laws is that they often incorporate several different ecosystems. At the same time they may stipulate degrees of conservation, given that livelihoods must still be derived from the protected areas. For example, in the case of the declared protected area of the Wiawi coastal community on Malekula, the forest is protected but the forest zone also includes plantations and gardens, while protection straddles the coastal zone, conserving turtle as well as reef zone resources (Tacconi 1995b).The eight kilometres of protected coast is currently subject to bans on the collections of trochus and green snail and to closure to fishing on six days a week.

Other conservation arrangements that depend on local jurisdictions exercising their customary rights include that of a Cook Island Council enforcing limited trochus harvesting. The arrangement features individual transferable quotas and inspections upon landing (World Bank 1995). In Solomon Islands, the maintenance of the Arnavon Marine Conservation Area depends on the cooperation, and coordination through the provision of rangers, of three village councils on Choisel and Ysabel, with the support of governments and nongovernment organisations, to enforce bans on the harvesting of turtle eggs.

Such inshore conservation regimes are most applicable in rural rather than peri-urban areas, where traditional authority is still strong. And the communities must be able to substitute alternative sources of subsistence and cash income during closures (World Bank 1995).

\section{Notes}

The author has benefited from the comments of Transform Aqorau but any omissions or errors are the author's sole responsibility.

1. This paper deals generally with the countries served by the SPC and in the case of industrial fishing by the FFA.

The island member countries of the FFA are: Cook Islands, Federated States of Micronesia, Fiji, Kiribati, Marshall Islands, 
Nauru, Niue, Palau, Papua New Guinea, Samoa, Solomon Islands, Tonga, Tuvalu and Vanuatu.

The 22 island members served by the SPC are: American Samoa, Cook Islands, Federated States of Micronesia, Fiji, French Polynesia, Guam, Kiribati, Marshall Islands, Nauru, Niue, New Caledonia, Northern Mariana Islands, Palau, Papua New Guinea, Pitcairn Islands, Samoa, Solomon Islands, Tokelau, Tonga, Tuvalu, Vanuatu, and Wallis and Futuna.

2. The US fee is set at US $\$ 18$ million for 10 years under the 1993 regional agreement. The US Tuna Boat Association receives a subsidy from the US government of US $\$ 14$ million and itself contributes US $\$ 4$ million. The fee of US $\$ 18$ million implies a rate of payment of 9 to 14 per cent of the value of tuna caught-this is a subsidised rate. Under the multilateral treaty with the United States, US\$1.8 million is paid annually into a project development fund administered by the FFA, 15 per cent of the balance is shared equally among the parties, and the remainder is divided between the parties according to the weight of catch taken from their EEZs (FFA 1996).

3. Federated States of Micronesia, Kiribati, Marshall Islands, Nauru, Palau, Papua New Guinea, Solomon Islands and Tuvalu.

4. In 1995 an attempt was made by a group of Pacific countries, Cook Islands, Fiji, Niue, Solomon Islands, Tokelau, Tonga, Vanuatu and Western Samoa, to negotiate a sub-regional agreement with representatives of the Taiwanese fishing interests that operate freezer longline vessels in the Pacific (FFA 1995). The group expressed dissatisfaction with the poor level of compliance in catch reporting and transhipment displayed by Taiwan vessel operators in the region. The resulting suspension of bilateral arrangements by some Pacific island countries in the group had caused part of the Taiwanese fleet to relocate to the eastern Pacific and the Indian Ocean. A sub-regional annual access fee of US $\$ 870,000$ for 75 vessels, and US $\$ 650,000$ for 50 or less, was proposed. However, the Taiwanese rejected the proposal out of hand on the grounds that the fee was too high when considered along with the impositions of prohibition of transhipment at sea (which was objected to) and compliance with observer programs and reporting.

5. This latter encouragement is through a cooperative arrangement by Pacific island countries party to the Nauru Agreement and the Palau Arrangement, and takes the form of licensing priorities and concessional access to purse-seine vessels prepared to invest, provision, and employ locally. An additional incentive to achieve the latter is a phased reduction in the number of licences available to foreign vessels while the number of licences available for localised vessels is increased. 
6. In the PNG bait fishery the allocation of part of the rents to a trust fund and to the provincial government, rather than to local groups, became a bone of contention (Turner 1994).

7. For every 1 per cent increase in collective access fee, an extra US $\$ 15$ million would flow to Pacific island countries (given the value of catch by distant water fleets was approximately US $\$ 1.5$ billion in 1995). If royalties could be increased to a level equivalent to 10 per cent of the value of catch, income to Pacific island countries would double, to some US $\$ 150$ million.

8. Awareness of the potential for local management of marine resources had already been raised by an education program conducted by the Vanuatu Fisheries Department and the Environment Unit.

9. Personal communication, Chief Timothy Nehapi, Wiawi Community, Malekula, Vanuatu, 20 June 1996.

\section{References}

Bennett, J., 1996. Highlights for 1995-96-an update of the 1994-95 Annual Report, Australian Council for International Agricultural Research (ACIAR) Project 9020, ACIAR, Canberra.

Boer, B., 1995. 'Environmental law and the South Pacific: law of the sea issues', in J. Crawford and D. Rothwell (eds), The Law of the Sea in the Asian Pacific region, Martinus Nijhoff, Dordrecht: 67-92.

Carrier, J., 1987. 'Marine tenure and conservation in PNG', in

B. McCay and J. Acheson (eds), The question of the commons: the culture and ecology of communal resources, University of Arizona Press, Tucson:142-67.

Cook, A., 1994. The quoliquoli of Fiji, MSc dissertation, University of Newcastle-Upon-Tyne.

Crawford, J., and D. Rothwell (eds), 1995. The Law of the Sea in the Asian Pacific region, Martinus Nijhoff, Dordrecht.

Crocombe, R., (ed.), 1987. Land Tenure in the Pacific, University of the South Pacific, Suva.

1994. 'Overview', in R. South, D. Goulet, S. Tuquiri and M. Church (eds), Proceedings of the international Workshop on Traditional Marine Tenure and Sustainable Management of Marine Resources in Asia and the Pacific, University of the South Pacific, Suva:291-300.

Dalzell, P., Adams, T., and Polunin, N., 1995. 'Coastal fisheries in the South Pacific', paper to the joint FFA/SPC workshop, Management of South Pacific Inshore Fisheries, 26 June-7 July, 1995, South Pacific Commission, Noumea, unpublished. 
Doulman, D., 1989. 'Japanese distant-water fishing in the South Pacific', Pacific Economic Bulletin 4 (2):22-8.

Ron Duncan and Ila Temu, 1996. Trade, investment and sustainable development of natural resources in the Pacific: the case of fish and timber, paper presented to the Economic and Social Commission for Asia and the Pacific Expert Group Meeting on Enhancing Cooperation in Trade and Investment Between Pacific island Countries and Economies of East and South East Asia in the 1990s, Port Vila, Vanuatu, July 8-12, 1996, unpublished.

ESCAP, forthcoming. Strengthening seafood export capabilities in the South Pacific, Proceedings of a workshop, ESCAP, Bangkok, 27-29 March, 1996.

Forum Fisheries Agency, 1995. Record of discussion, meeting of Pacific island countries and the Taiwan Deep Sea Tuna Boatowners and Exporters Association to discuss a regional licensing agreement for longline vessels, Brisbane 8-19 May, 1995, Forum Fisheries Agency, Honiara.

- 1996. Treaty on Fisheries with the USA: seventh licensing period, distribution of the 85 per cent shares, Forum Fisheries Agency, Honiara.

Hunt, C., 1996. 'Tackling environmental threats on Pacific atolls', Pacific Economic Bulletin 11(2):58-69.

- 1996. 'Property rights and environmental management on Pacific atolls', International Journal of Social Economics 23:221-34.

Hviding, E., 1996. Guardians of Marovo Lagoon: practice, place, and politics in maritime Melanesia, University of Hawaii Press, Honolulu.

Hyndman, D., 1993. 'Sea tenure and the management of living marine resources in PNG', Pacific Studies 16 (4):99-114.

Islands Business Pacific, 1994. January:46.

Johannes, R., 1978. 'Traditional marine conservation methods in

Oceania and their demise', Annual Review of Ecological Systems 9: 349-64.

- 1994 a. 'Design of tropical nearshore fisheries extension work beyond the $1990 \mathrm{~s}^{\prime}$, in R. South, D. Goulet, S. Tuquiri and M. Church (eds), Proceeding of the international workshop on traditional marine tenure and sustainable management of marine resources in Asia and the Pacific, University of the South Pacific, Suva:162-74.

— $1994 \mathrm{~b}$. 'Government supported village-based management of marine resources in Vanuatu', Forum Fisheries Agency Report 94/ 7, Forum Fisheries Agency, Honiara. 
McCay, B., and J. Acheson (eds), 1987. The question of the commons: the culture and ecology of communal resources, University of Arizona Press, Tucson.

Maxwell, J., and Owen, A., 1994. South Pacific Tuna Fisheries Study, AusAID, Canberra.

Pacific Report, 1995. 8(18):5.

Pacific Report, 1996. 9(18):3.

Petelo, A., Matoto, S., and Gillett, R., 1995. 'The case for communitybased fisheries management in Tonga', Paper to the joint FFA/SPC workshop, Management of South Pacific Inshore Fisheries, 26 June-7 July, South Pacific Commission, Noumea.

Pulea, M., 1993. An overview of constitutional and legal provisions relevant to customary marine tenure and management systems in the South Pacific. FFA Report 93/23. Forum Fisheries Agency, Honiara.

Scheffler, H. and Larmour, P., 1987. 'Solomon Islands: evolving a new custom', in R. Crocombe (ed.), Land Tenure in the Pacific, University of the South Pacific, Suva:303-23.

South, R., Goulet, D., Tuquiri, S. and Church, M., (eds), 1994.

Proceedings of the international Workshop on Traditional Marine Tenure and Sustainable Management of Marine Resources in Asia and the Pacific, University of the South Pacific, Suva.

South Pacific Commission, 1994a. Tuna Fishery Yearbook, South Pacific Commission, Noumea.

- 1994 b. By-catch and discards in western Pacific tuna fisheries: a review of SPC data holdings and literature, Oceanic Fisheries Programme Internal Report 28, South Pacific Commission, Noumea.

- 1995. Work programme review 1994-95 and work plan 1995-96, Oceanic Fisheries Programme, South Pacific Commission, Noumea.

- 1996. Status of tuna stocks in the western and central Pacific Ocean, Paper to the Forum Fisheries Committee, 13-17 May, Vava'u, Kingdom of Tonga.

South Pacific Project Facility, 1996. Papua New Guinea Fishing Industry

Seminar-tuna longlining, South Pacific Project Facility, Sydney.

Tacconi, L., 1995a. 'Participatory conservation in Malekula Island, Vanuatu, Research Report 10, University of New South Wales University College, Canberra. 
1995b. Proposal for the establishment of the Nagha Mo Pineia Protected Area, Research Report 11, University of New South Wales University College, Canberra.

Tsamenyi, B., and Mfodwo, K., 1995. 'South Pacific island states and the new regime of fisheries: issues of law, economy and diplomacy', in J. Crawford and D. Rothwell (eds), The Law of the Sea in the Asian Pacific region, Martinus Nijhoff, Dordrecht:121-53.

Turner, J., 1994. 'Sea change: adapting customary marine tenure to commercial fishing: the case of the Papua New Guinea bait fishery', in R. South, D. Goulet, S. Tuquiri and M. Church (eds), Proceeding of the international workshop on traditional marine tenure and sustainable management of marine resources in Asia and the Pacific, University of the South Pacific, Suva:141-54.

United Nations, 1982. The United Nations Convention on the Law of the Sea, United Nations General Assembly, New York.

- 1995. The United Nations Conference on Straddling Fish Stocks and Highly Migratory Fish Stocks, United Nations General Assembly, New York.

- no date. 'Protection of the oceans and all kinds of seas, including semi-enclosed seas and coastal areas and the protection and rational use and development of their living resources', paper jointly prepared by the UN Office for Ocean Affairs and the Law of the Sea, United Nations, New York.

Vanuatu Government, 1993. Vanuatu National Parks Act, No, 7, of 1993, Port Vila.

World Bank, 1995. Pacific Island Economies: building a resilient economic base for the twenty first century, World Bank, Washington DC. 